\title{
Anthropogenic carbon distributions in the Atlantic Ocean: data-based estimates from the Arctic to the Antarctic
}

\author{
M. Vázquez-Rodríguez ${ }^{1}$, F. Touratier ${ }^{2}$, C. Lo Monaco ${ }^{3}$, D. W. Waugh ${ }^{4}$, X. A. Padin ${ }^{1}$, R. G. J. Bellerby ${ }^{5,6}$, C. Goyet $^{2}$, \\ N. Metzl $^{3}$, A. F. Ríos ${ }^{1}$, and F. F. Pérez ${ }^{1}$ \\ ${ }^{1}$ Instituto de Investigaciones Marinas, CSIC, Eduardo Cabello 6, 36208 Vigo, Spain \\ ${ }^{2}$ IMAGES, Université de Perpignan, 52 avenue Paul Alduy, 66860 Perpignan, France \\ ${ }^{3}$ LOCEAN/IPSL, Université Pierre et Marie Curie, case 100, 75252 Paris cedex 05, France \\ ${ }^{4}$ Department of Earth and Planetary Sciences, Johns Hopkins University, Baltimore, USA \\ ${ }^{5}$ Bjerknes Centre for Climate Research, University of Bergen, Allégaten 55, 5007 Bergen, Norway \\ ${ }^{6}$ Geophysical Institute, University of Bergen, Allégaten 70, 5007 Bergen, Norway
}

Received: 4 March 2008 - Published in Biogeosciences Discuss.: 7 April 2008

Revised: 21 January 2009 - Accepted: 9 March 2009 - Published: 18 March 2009

\begin{abstract}
Five of the most recent observational methods to estimate anthropogenic $\mathrm{CO}_{2}\left(\mathrm{C}_{\text {ant }}\right)$ are applied to a highquality dataset from five representative sections of the Atlantic Ocean extending from the Arctic to the Antarctic. Between latitudes $60^{\circ} \mathrm{N}-40^{\circ} \mathrm{S}$ all methods give similar spatial distributions and magnitude of $\mathrm{C}_{\mathrm{ant}}$. However, discrepancies are found in some regions, in particular in the Southern Ocean and Nordic Seas. The differences in the Southern Ocean have a significant impact on the anthropogenic carbon inventories. The calculated total inventories of $\mathrm{C}_{\mathrm{ant}}$ for the Atlantic referred to 1994 vary from 48 to $67 \mathrm{Pg}\left(10^{15} \mathrm{~g}\right)$ of carbon, with an average of $54 \pm 8 \mathrm{PgC}$, which is higher than previous estimates. These results, both the detailed $\mathrm{C}_{\text {ant }}$ distributions and extrapolated inventories, will help to evaluate biogeochemical ocean models and coupled climate-carbon models.
\end{abstract}

\section{Introduction}

Understanding and modelling the marine carbon system is one of the pressing issues within the framework of climate change. Carbon dioxide, an important greenhouse gas, is being increasingly produced by human activities, adding to the "natural" carbon cycle. International research has made progressive efforts to monitor the evolution of the oceanic sink of atmospheric $\mathrm{CO}_{2}$, and in understanding how human

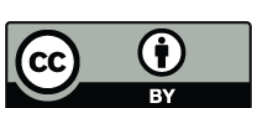

Correspondence to:

M. Vázquez-Rodríguez

(mvazquez@iim.csic.es) activities interfere with this air-sea coupled system. One of the grand aims of this effort is to accurately assess the future possible scenarios proposed by the Intergovernmental Panel on Climate Change (IPCC Fourth Assessment Report: Climate Change $2007^{1}$ ). The invasion of anthropogenic $\mathrm{CO}_{2}$ $\left(\mathrm{C}_{\mathrm{ant}}\right)$ in the ocean impacts not only the atmospheric carbon dioxide concentrations and is associated to climate change, but has also a direct effect on ocean chemistry, causing the so-called "ocean acidification" (Feely et al., 2004). The largest ocean acidification influences for the environment are expected to occur in the high northern and southern latitudes (Bellerby et al., 2005; Orr et al., 2005).

In this context, estimating $\mathrm{C}_{\mathrm{ant}}$ concentrations in the oceans represents an important step towards a better evaluation of the global carbon budget and its rates of change. Since $\mathrm{C}_{\text {ant }}$ may not be directly measured in the ocean it has to be derived from in-situ observations, under several assumptions. The pioneering original works by Brewer (1978) and Chen and Millero (1979) addressed this issue, and estimated $C_{a n t}$ in Atlantic subsurface water masses of the Atlantic Ocean from total inorganic carbon $\left(\mathrm{C}_{\mathrm{T}}\right)$ measurements. They corrected the measured $\mathrm{C}_{\mathrm{T}}$ for the effect of organic matter remineralization (ROM) and made an estimate of the preformed Preindustrial $\mathrm{C}_{\mathrm{T}}\left(\mathrm{C}_{\mathrm{T}}\right.$ when the water was last in contact with the 1850 atmosphere). Together with the ROM contribution this preindustrial $\mathrm{C}_{\mathrm{T}}$ was also subtracted from the observed $\mathrm{C}_{\mathrm{T}}$. In the last ten years, several observational (data-based) methods have been investigated at regional and global scales (see Wallace et al., 2001 for a historical overview). Two of

\footnotetext{
${ }^{1}$ http://www.ipcc.ch/
}

Published by Copernicus Publications on behalf of the European Geosciences Union. 
them, the $\Delta C^{*}$ method (Gruber et al., 1996) and the Transient Time Distribution (TTD) method (Hall et al., 2002) have been applied at global scale. By using the $\Delta \mathrm{C}^{*}$ approach, Sabine et al. (2004) estimated a global oceanic inventory of $C_{a n t}$ for a nominal year of 1994 of $118 \pm 19 P g$ C, which represents about $45 \%$ of the fossil fuel $\mathrm{CO}_{2}$ emitted between 1800 and 1994. Similarly, Waugh et al. (2006) applied the TTD method to estimate the $\mathrm{C}_{\text {ant }}$ inventory for the global ocean and obtained results ranging between 94 and $121 \mathrm{Pg} \mathrm{C}$ for 1994 . These authors also compared the $\mathrm{C}_{\text {ant }}$ distribution derived from the $\Delta C^{*}$ and TTD approaches and pointed out that in spite of the grand-scale reasonable agreement, substantial differences occurred in the North Atlantic, South-Eastern Atlantic and in all basins south of $30^{\circ} \mathrm{S}$. This was an important result as it offered a range of $\mathrm{C}_{\mathrm{ant}}$ concentrations to be used as a benchmark to be checked with ocean carbon cycle models. Analogous results were derived from intercomparison studies carried out with Ocean General Circulation Models (OGCM) (Orr et al., 2001), i.e.: reasonable agreement was found for ocean-wide inventories but significant differences prevailed at a regional scale in terms of inventory and as to where $C_{\text {ant }}$ was actually located, especially in the high latitudes and between the upper and lower ocean. Estimating accurate oceanic $\mathrm{C}_{\text {ant }}$ inventories does not only provide a good constraint for predictive ocean models. They are also key input parameters in inverse models for calculating air-sea fluxes of $\mathrm{C}_{\mathrm{ant}}$ (Gloor et al., 2003; MikaloffFletcher et al., 2006; Gerber et al., 2009) and global budgets of the carbon cycle (IPCC, 2007).

In more recent years, additional data-based methods were developed in an attempt to improve the existing oceanic $\mathrm{C}_{\mathrm{ant}}$ estimates, especially at a regional level. These are the TrOCA method (Touratier and Goyet, 2004; Touratier et al., 2007), the $\mathrm{C}_{\text {IPSL }}^{\circ}$ method (Lo Monaco et al., 2005a) and the $\varphi \mathbf{C}_{\mathrm{T}}^{\circ}$ method. To date, only few of these observational methods, including the $\Delta C^{*}$, have been objectively inter-compared, and that is at regional scales only, namely: in the North Atlantic (Wanninkhof et al., 1999; Friis et al., 2006; Tanhua et al., 2007), the North Indian (Coatanoan et al., 2001), or along a single section in the Southern Ocean (Lo Monaco et al., 2005b). All of these studies identified significant discrepancies in $\mathrm{C}_{\text {ant }}$ distributions and specific inventories depending on the location, set of compared $\mathrm{C}_{\mathrm{ant}}$ estimation approaches and methodological assumptions.

Today, there is a pressing need to compare and clarify the $\mathrm{C}_{\mathrm{ant}}$ estimates from these various observational methods, as it has been analogously addressed in the case of ocean carbon models (OCMIP project; Orr et al., 2001), atmospheric inverse models (Gurney et al., 2004), or coupled climatecarbon models (C4MIP project ${ }^{2}$ ).

\footnotetext{
${ }^{2}$ http://www.atmos.berkeley.edu/c4mip/
}

As a contribution to the European integrated project of CARBOOCEAN, this international collaborative study will focus on the comparison of results from five different approaches used to estimate anthropogenic $\mathrm{CO}_{2}$ concentrations. This is done from a single and common high-quality data set from modern cruises conducted in the Atlantic Ocean, including the Arctic and Southern Ocean sectors. The results will identify the areas of greatest discrepancies and uncertainty amongst methods. Based on the fundamentals and main assumptions of the methods some adjustments will be proposed to try to improve the estimates and reconcile methods upon. In addition, the results will also serve observational and numerical ocean modellers to evaluate their simulations and will help to reach a consensus as to where $C_{\text {ant }}$ is captured and actually stored. The analysis in the present work investigates the high latitudes (Southern Ocean and Nordic Seas) as locations where uncertainties are expected to be large for both data-based methods (Lo Monaco et al., 2005b; Waugh et al., 2006) and OGCMs (Orr et al., 2001). The Atlantic Ocean has been selected here because it has the largest $\mathrm{C}_{\mathrm{ant}}$ specific inventory of all ocean basins, and also because of its large meridional and zonal gradients of $\mathrm{C}_{\mathrm{ant}}$ (Sabine et al., 2004; Waugh et al., 2006). The paper first describes the various $\mathrm{C}_{\mathrm{ant}}$ meridional and zonal distributions, according to the different methods applied, focusing on key areas (of water masses formation and transformation). The specific and total $\mathrm{C}_{\mathrm{ant}}$ inventories are then presented and discussed on the basis of the main assumptions from the methods as possible sources for the observed dissimilarities.

\section{Method}

Data from four selected meridional sections (NSeas-Knorr, CLIVAR A16N, WOCE I06-Sb and WOCE A14) cover the length of the Atlantic and give a representative coverage of it (Fig. 1a). The WOCE AR01 extends from the Atlantic east to west ends at $\sim 24^{\circ} \mathrm{N}$ (Fig. 2a). They have all been recently conducted within the framework of either the WOCE or CLIVAR programs, except for the cruise in the Nordic Seas (NSeas, 2005) on board the R/V Knorr (Bellerby et al., 2005; Olsen et al., 2006). The data are available from the GLODAP website ${ }^{3}$, except for the NSeas data ${ }^{4}$ and the CLIVAR repeat section A16N legs 1 and 2 conducted during $2003^{5}$. The selected cruises correspond to different years and thus $\mathrm{C}_{\text {ant }}$ results had to be referred to the common year 1994 (GLODAP canonical year) to eliminate biases introduced by the effect of increasing fugacity of atmospheric $\mathrm{CO}_{2}\left(f \mathrm{CO}_{2}\right)$. This was done using data from time series of $\mathrm{CO}_{2}$ molar fractions $\left(x \mathrm{CO}_{2}\right)$ and calculating from here the ratio of $\mathrm{C}_{\mathrm{ant}}$ saturation concentrations for the year of the

\footnotetext{
${ }^{3}$ http://cdiac.ornl.gov/oceans/glodap/Glodap_home.htm

${ }^{4}$ http://cdiac.ornl.gov/ftp/oceans/CARINA/Knorr/ 316N20020530/

${ }^{5}$ http://www.clivar.org/carbon_hydro/hydro_table.php
} 

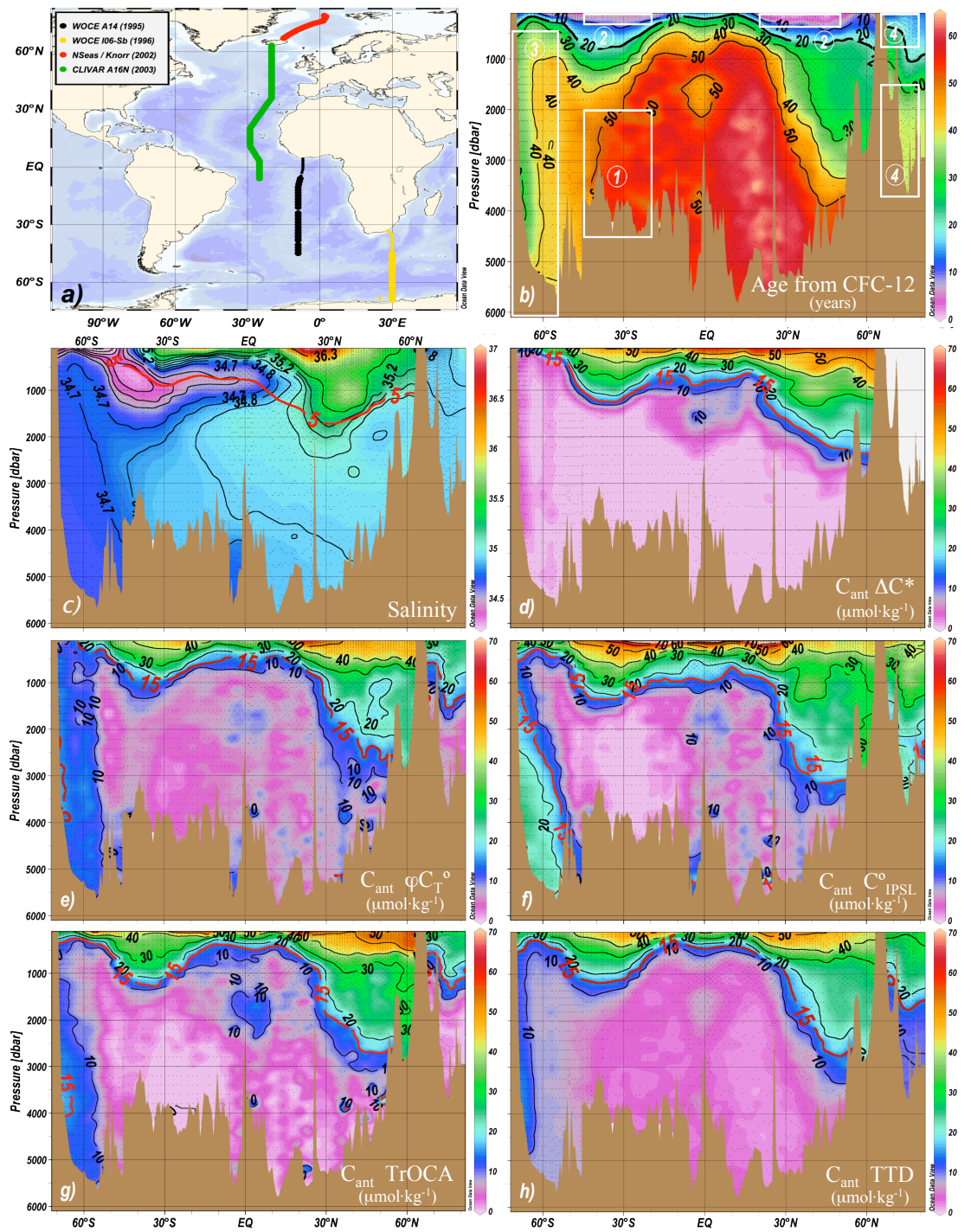

Fig. 1. (a) Map showing the considered meridional cruises WOCE A14, WOCE I06-Sb, CLIVAR A16N and NSeas/Knorr conducted in the Atlantic. Thinner dots in cruises A14 and I06-Sb represent stations not used (latitudinal overlapping of different cruises); (b) age (years) of water masses in the meridional transects from (a), calculated using CFC12. The inlayed rectangles delimit the regions where $\mathrm{C}_{\text {ant }}$ estimates are given a closer look, namely: 1=deep South Atlantic, $2=$ northern and southern subtropical gyres, $3=$ Southern Ocean and $4=$ The Nordic Seas; (c) salinity distribution of the meridional transect displaying the $5^{\circ} \mathrm{C}$ isotherm that separates the large volume of cold waters $(\sim 86 \%$ of the Atlantic Ocean volume) from warmer surface waters; (d-h) estimates of anthropogenic $\mathrm{CO}_{2}\left(\mu \mathrm{mol} \mathrm{kg}{ }^{-1}\right)$ in the meridional transect from the $\Delta \mathrm{C}^{*}, \varphi \mathrm{C}_{\mathrm{T}}^{\circ}, \mathrm{C}_{\mathrm{IPSL}}^{\circ}$, TrOCA and TTD methods, respectively. The red $15 \mu \mathrm{mol} \mathrm{kg}^{-1}$ isopleth separates the region of maximum $\mathrm{C}_{\text {ant }}$ gradient from deeper waters.

cruise and the preindustrial era. The correction typically varied between 1-7 $\mu \mathrm{mol} \mathrm{kg} \mathrm{kg}^{-1}$ of $\mathrm{C}_{\text {ant }}$ depending on the sampling year, the potential temperature and salinity of the samples. Another consideration has been the overlapping latitudes of the A16N-A14 and A14-I06Sb section pairs. The general selection criteria followed was choosing the stations that were deepest and had the least influence of Indian Ocean waters. Accordingly, the northernmost ends of the A14 and I06Sb cruises are omitted from the plots (Fig. 1a). Finally, negative $C_{a n t}$ estimates that were within the specific range of uncertainty in each method were set to zero (ad hoc), while values more negative than that were taken as outliers and excluded from subsequent analysis.

Five data-based methods for $\mathrm{C}_{\mathrm{ant}}$ estimation have been considered in this study: the TTD (Waugh et al., 2006), the TrOCA (Touratier et al., 2007), the C $\mathrm{C}_{\mathrm{IPSL}}^{\circ}$ (Lo Monaco et al., 2005a) and the $\varphi \mathrm{C}_{\mathrm{T}}^{\circ}$. The $\Delta \mathrm{C}^{*}$ method has been included in this comparison, but it has not been applied to the same data-set. The $\mathrm{C}_{\text {ant }}$ results here shown correspond to the same cruises though (except for the NSeas-Knorr one), taken 

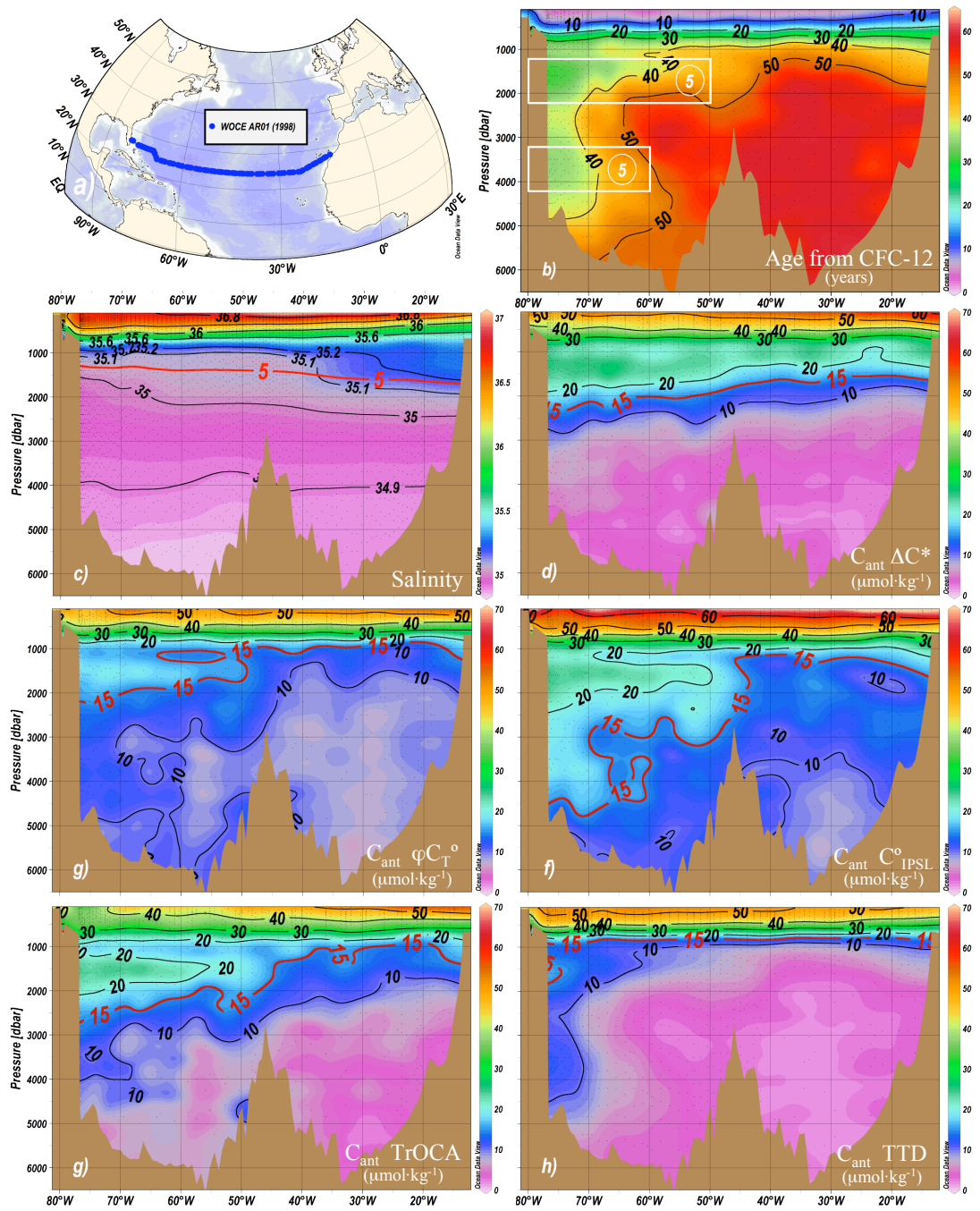

Fig. 2. Analogous contour plots to Fig. 1 for the zonal cruise WOCE AR01. From top to bottom and left to right: (a) cruise map, (b) CFC12 age in years showing the $u \mathrm{DWBC}$ and $l \mathrm{DWBC}$ limbs in white-contoured boxes numbered as " 5 "; (c) salinity field with the red $5^{\circ} \mathrm{C}$ isotherm overlaid; $(\mathbf{d}-\mathbf{h}) \mathrm{C}_{\text {ant }}$ concentration estimates $\left(\mu \mathrm{mol} \mathrm{kg}^{-1}\right)$ from the $\Delta \mathrm{C}^{*}, \varphi \mathrm{C}_{\mathrm{T}}^{\circ}, \mathrm{C}_{\mathrm{IPSL}}^{\circ}$, TrOCA and TTD methods, respectively.

from the $\mathrm{C}_{\mathrm{ant}}$ appearing in the GLODAP dataset as of Lee et al. (2003). They have applied the $\Delta C^{*}$ method to evaluate the inventory of $\mathrm{C}_{\mathrm{ant}}$ in the eastern and western basins of the Atlantic. Their $\mathrm{C}_{\mathrm{ant}}$ estimates have been included in the global synthesis of Sabine et al. (2004) and the GLODAP database (Key et al., 2004). The data used and $C_{\text {ant }}$ results obtained using the above methods are available under the Carboocean data portal to facilitate further comparisons with OGCM outputs, for instance, that are beyond the scope of the present work. The above methods can be classified into two groups on the basis of the variables needed to compute $\mathrm{C}_{\mathrm{ant}}$ : a) the Transient-Tracer-based methods (TTD) that commonly use CFC11 or CFC12 concentration measurements as proxies of the anthropogenic $\mathrm{CO}_{2}$ signal and $\mathrm{b}$ ) the Carbon-based methods $\left(\Delta \mathrm{C}^{*}, \mathrm{C}_{\mathrm{IPSL}}^{\circ}, \varphi \mathrm{C}_{\mathrm{T}}^{\circ}\right.$ and TrOCA) which typically require measurements of dissolved inorganic carbon $\left(\mathrm{C}_{\mathrm{T}}\right)$, total alkalinity $\left(\mathrm{A}_{\mathrm{T}}\right)$, oxygen, temperature and eventually salinity and some nutrient analysis. They all make a steady-state assumption in terms of seasonal and interannual variability of the natural carbon cycle.

The Transient Time Distribution (TTD) is an indirect method that uses measurements of transient tracers (in particular CFCs) to estimate $\mathrm{C}_{\text {ant }}$ without the use of carbon measurements. The TTD method considers that there is a distribution of ventilation times (Hall et al., 2002), which is much more appropriate than the single ventilation time assumption from the early "shortcut" method by Thomas and Ittekot (2001). The considered transient time distribution assumes that advection $(\Gamma)$ and mixing $(\Delta)$ processes are globally of the same order of magnitude $(\Delta / \Gamma=1)$. The air-sea 
$\mathrm{CO}_{2}$ disequilibrium is considered to be constant over time, but not in space. The use of $p$ CFC12 age to calculate the date of formation of the water masses is a potential positive bias in the method. This is because the CFC12 history is shorter and more nonlinear than surface $\mathrm{C}_{\mathrm{ant}}$, and using the CFC12 age as the single ventilation means one looks too recently in the surface $\mathrm{C}_{\text {ant }}$ history and overestimates $\mathrm{C}_{\text {ant }}$ (Hall et al., 2002). This bias tends to increase with $p$ CFC12 age, and is expected to be large for deep waters with $p$ CFC12 ages greater than 25 years (Matear et al., 2003).

The classical $\Delta \mathrm{C}^{*}$ approach is fundamentally based on the preformed $\mathrm{C}_{\mathrm{T}}$ back-calculation principles established by Brewer (1978) and Chen and Millero (1979). To constitute a measure of $\mathrm{C}_{\mathrm{ant}}$ in a water sample the method back-calculates the $\mathrm{C}_{\mathrm{T}}$ of a water sample to its initial (preformed) $\mathrm{C}_{\mathrm{T}}$ concentration when it was last at surface on the basis of the changes in $\mathrm{A}_{\mathrm{T}}, \mathrm{AOU}$, salinity and $\theta$. The $\Delta \mathrm{C}^{*}$ approach is principally based on two assumptions: a) the anthropogenic $\mathrm{CO}_{2}$ invasion has not altered surface alkalinity, so that it is unnecessary to differentiate between historical and present preformed alkalinity $\left(\mathrm{A}_{\mathrm{T}}^{\circ}\right)$ values and $\mathrm{b}$ ) constant air-sea $\mathrm{CO}_{2}$ disequilibrium $\left(\Delta \mathrm{C}_{\mathrm{dis}}\right)$ over time at the source region of the sampled water (steady state assumption). The method first introduced the $\Delta \mathrm{C}_{\text {dis }}$ term to the back-calculation techniques and proposed a formal way to estimate it. In old water masses, according to a $p \mathrm{CFC} 11$ age criteria, $\mathrm{C}_{\mathrm{ant}}$ was automatically set to zero and $\Delta \mathrm{C}_{\mathrm{dis}}$ was assigned the value of the quasi-conservative tracer $\Delta \mathrm{C}^{*}$. For younger water masses, the $\Delta \mathrm{C}_{\mathrm{dis}}$ had to be estimated using the "shortcut" method (Thomas and Ittekot, 2001) to calculate $\mathrm{C}_{\mathrm{ant}}$ directly on those waters, based on their CFC11 content. One caveat to this procedure is that it can misleadingly prone to think that all waters void of CFCs are unaffected by $\mathrm{C}_{\text {ant }}$ (Matear et al., 2003). Knowingly, this conjecture introduces negative biases on the $\Delta C^{*}$ (Matsumoto and Gruber, 2005). It must alternatively be noticed that the $\Delta C^{*}$ approach considers that waters are fully saturated with oxygen and CFCs at the instant of their outcropping.

The $\mathrm{C}_{\text {IPSL }}^{\circ}$ method is based on the original $\mathrm{C}^{\circ}$ method described in the works by Brewer (1978) and Chen and Millero (1979). Differently, it allows for air-sea oxygen disequilibria. In most regions of the world ocean (including the North Atlantic) the preformed oxygen is close to equilibrium with the atmosphere. In the Southern Ocean, the upwelling of oxygen-exhausted waters provokes a deficit in surface oxygen concentrations of up to $50 \mu \mathrm{mol} \mathrm{kg}^{-1}$ (Poisson and Chen, 1987). A mean oxygen under-saturation coefficient $\alpha=12 \%$ calculated in the Weddell Sea area (Anderson et al., 1991) was used for $C_{\text {ant }}$ calculation in ice-covered surface waters. This method uses different preformed relationships of $\mathrm{A}_{\mathrm{T}}^{\circ}$ and $\mathrm{C}_{\mathrm{T}}^{\circ}$ for southern and northern Atlantic waters. The relationships for the Southern Hemisphere were determined from winter data collected in surface waters $(0-50 \mathrm{~m})$ in the Atlantic and Indian Oceans. Northern relationships were determined using subsurface measurements (50-150 m) collected in the North Atlantic and Nordic Seas. The specific contributions of northern and southern waters are introduced in the equations via a specific north-south mixing ratio " $k$ ". The coefficients for each sample are determined with a multiple end-member mixing model they resolved via an optimum multiparameter (OMP) analysis. The $R_{\mathrm{C}}$ and $R_{\mathrm{N}}$ stoichiometric ratios used are the ones determined by Anderson and Sarmiento (1994). The preindustrial $C_{a n t}$ reference is calculated from North Atlantic Deep Water (NADW) detected in the South Atlantic, where $\mathrm{C}_{\text {ant }}$ concentrations are below detection limits. This zero- $\mathrm{C}_{\mathrm{ant}}$ baseline reference corresponds to the increase in $\mathrm{C}_{\mathrm{T}}^{\circ}$ in the source region since the preindustrial era, and although it is a time-dependent parameter it is applied as a constant $\left(-51 \mu \mathrm{mol} \mathrm{kg}^{-1}\right)$.

The $\varphi \mathbf{C}_{\mathrm{T}}^{\circ}$ method is another process-oriented biogeochemical approach to estimate $\mathrm{C}_{\mathrm{ant}}$ in the Atlantic that follows the same fundamental principles as the $\Delta \mathrm{C}^{*}$ or $\mathrm{C}_{\mathrm{IPSL}}^{\circ}$ backcalculation methods. The subsurface layer $(100-200 \mathrm{~m})$ is taken in the $\varphi \mathbf{C}_{\mathrm{T}}^{\circ}$ method as a reference for characterising water mass properties at the moment of their formation. The airsea disequilibrium $\left(\Delta \mathrm{C}_{\mathrm{dis}}\right)$ is parameterized at the subsurface layer first using a shortcut method to estimate $\mathrm{C}_{\mathrm{ant}}$. Since the average age of the water masses in the 100-200 m depth domain, and most importantly in outcropping regions, is under 25 years, the use of the shortcut method to estimate $\mathrm{C}_{\text {ant }}$ is appropriate (Matear et al., 2003). The $\mathrm{A}_{\mathrm{T}}^{\circ}$ and $\Delta \mathrm{C}_{\text {dis }}$ parameterizations (in terms of conservative tracers) obtained from subsurface data are applied directly to calculate $\mathrm{C}_{\mathrm{ant}}$ in the water column for waters above the $5^{\circ} \mathrm{C}$ isotherm and via an OMP analysis for waters with $\theta<5^{\circ} \mathrm{C}$. This approach especially improves the estimates in cold deep waters that are subject to strong and complex mixing processes between Arctic and Antarctic water masses and represent an enormous volume of the global ocean $(\sim 86 \%)$. One important aspect in this process is that none of the $\mathrm{A}_{\mathrm{T}}^{\circ}$ or $\Delta \mathrm{C}_{\text {dis }}$ parameterizations are CFC-reliant. The $\varphi \mathrm{C}_{\mathrm{T}}^{\circ}$ method proposes an approximation to the horizontal (spatial) and vertical (temporal) variability of $\Delta \mathrm{C}_{\mathrm{dis}}\left(\Delta \Delta \mathrm{C}_{\mathrm{dis}}\right)$ in the Atlantic Ocean in terms of $\mathrm{C}_{\mathrm{ant}}$ and $\Delta \mathrm{C}_{\mathrm{dis}}$ itself. Also, the small increase of $\mathrm{A}_{\mathrm{T}}^{\circ}$ since the Industrial era due to $\mathrm{CaCO}_{3}$ dissolution changes projected from models (Heinze, 2004) and the effect of rising sea surface temperatures on the parameterized $\mathrm{A}_{\mathrm{T}}^{\circ}$ are accounted for. These two last corrections are minor but should still be considered if a maximum $4 \mu \mathrm{mol} \mathrm{kg}^{-1}$ bias $\left(2 \mu \mathrm{mol} \mathrm{kg}^{-1}\right.$ on average) in $\mathrm{C}_{\mathrm{ant}}$ estimates wants to be avoided.

The TrOCA method can be applied in the global ocean and it is based on a conservative tracer (the TrOCA) defined from oxygen, $\mathrm{C}_{\mathrm{T}}$ and $\mathrm{A}_{\mathrm{T}}$, similarly to classical conservative tracers such as "NO" or "PO" (Broecker, 1974). It shares with other process-based $\mathrm{C}_{\text {ant }}$ methods its consideration of the $\mathrm{CaCO}_{3}$ dissolution chemistry and the ROM processes as defined in the Redfilian equations. The $\mathrm{C}_{\mathrm{ant}}$ concentration is estimated by subtracting from TrOCA a zero- $\mathrm{C}_{\mathrm{ant}}$ reference $\left(\mathrm{TrOCA}^{\circ}\right)$ defined from the "natural" concentrations of $\mathrm{O}_{2}, \mathrm{C}_{\mathrm{T}}$ and $\mathrm{A}_{\mathrm{T}}$. It is assumed that $\mathrm{A}_{\mathrm{T}}$ is not affected by 
Table 1. Summary statistics for the regions highlighted in Figs. $1 \mathrm{~b}$ and $2 \mathrm{~b}$.

\begin{tabular}{|c|c|c|c|c|c|c|c|c|c|c|c|c|c|}
\hline Region & Lat. & Long. & $\begin{array}{l}\text { Depth } \\
\text { (m) }\end{array}$ & $\begin{array}{c}\theta \\
\left({ }^{\circ} \mathrm{C}\right)\end{array}$ & Salinity & $\begin{array}{c}p \mathrm{CFC} 12 \\
(\mathrm{pmol} / \mathrm{kg})\end{array}$ & $\begin{array}{c}\text { Age CFC12 } \\
\text { (years) }\end{array}$ & $\begin{array}{c}\mathrm{AOU} \\
(\mu \mathrm{mol} / \mathrm{kg})\end{array}$ & $\begin{array}{c}\mathrm{C}_{\mathrm{ant}} \\
\Delta \mathrm{C}^{*} \\
(\mu \mathrm{mol} / \mathrm{kg})\end{array}$ & $\begin{array}{c}\mathrm{C}_{\text {ant }} \\
\varphi \mathrm{C}_{\mathrm{T}}^{\circ} \\
(\mu \mathrm{mol} / \mathrm{kg})\end{array}$ & $\begin{array}{c}\mathrm{C}_{\mathrm{ant}} \\
\mathrm{C}_{\mathrm{IPSL}}^{\circ} \\
(\mu \mathrm{mol} / \mathrm{kg})\end{array}$ & $\begin{array}{c}\mathrm{C}_{\mathrm{ant}} \\
\text { TrOCA } \\
(\mu \mathrm{mol} / \mathrm{kg})\end{array}$ & $\begin{array}{c}\mathrm{C}_{\mathrm{ant}} \\
\mathrm{TTD} \\
(\mu \mathrm{mol} / \mathrm{kg})\end{array}$ \\
\hline $\begin{array}{l}\text { Deep South } \\
\text { Atlantic } \\
\text { N. Subtropical }\end{array}$ & $20^{\circ} \mathrm{S}-45^{\circ} \mathrm{S}$ & $8^{\circ} \mathrm{W}$ & $>2000$ & $2.0 \pm 0.3$ & $34.85 \pm 0.04$ & $0.01 \pm 0.01$ & $53 \pm 4$ & $100.7 \pm 11$ & $0.1 \pm 0.5$ & $3.3 \pm 0.2$ & $0.2 \pm 0.5$ & $0.4 \pm 1.0$ & $2.8 \pm 0.1$ \\
\hline $\begin{array}{l}\text { Gyre } \\
\text { S. Subtropical }\end{array}$ & $20^{\circ} \mathrm{N}-50^{\circ} \mathrm{N}$ & $20^{\circ} \mathrm{W}$ & $100-350$ & $15.6 \pm 2.6$ & $36.18 \pm 0.43$ & $1.56 \pm 0.19$ & $4 \pm 4$ & $31.3 \pm 21$ & $42.8 \pm 0.6$ & $48.7 \pm 0.5$ & $50.1 \pm 0.9$ & $47.8 \pm 0.5$ & $46.1 \pm 0.4$ \\
\hline Gyre & $20^{\circ} \mathrm{S}-45^{\circ} \mathrm{S}$ & $8^{\circ} \mathrm{W}$ & $100-300$ & $13.1 \pm 3.5$ & $35.19 \pm 0.46$ & $1.40 \pm 0.21$ & $7 \pm 2$ & $29.2 \pm 18$ & $44.0 \pm 0.6$ & $41.3 \pm 0.7$ & $52.3 \pm 1.0$ & $37.8 \pm 0.6$ & $43.8 \pm 0.4$ \\
\hline $\begin{array}{l}\text { Southern Ocean } \\
\text { upper Nordic }\end{array}$ & $55^{\circ} \mathrm{S}-72^{\circ} \mathrm{S}$ & $30^{\circ} \mathrm{E}$ & $>500$ & $0.1 \pm 0.6$ & $34.68 \pm 0.02$ & $0.19 \pm 0.13$ & $37 \pm 4$ & $125.6 \pm 11$ & $1.5 \pm 1.6$ & $12.8 \pm 0.1$ & $16.4 \pm 0.4$ & $11.1 \pm 0.2$ & $9.9 \pm 0.1$ \\
\hline $\begin{array}{l}\text { Seas } \\
\text { lower Nordic }\end{array}$ & $65-79^{\circ} \mathrm{N}$ & $0-20^{\circ} \mathrm{W}$ & $100-750$ & $-0.2 \pm 0.5$ & $34.88 \pm 0.05$ & $2.50 \pm 0.46$ & $17 \pm 4$ & $25.7 \pm 12$ & Null & $23.2 \pm 1.1$ & $38.2 \pm 1.1$ & $24.2 \pm 1.2$ & $28.1 \pm 0.5$ \\
\hline Seas & $65-79^{\circ} \mathrm{N}$ & $0-20^{\circ} \mathrm{W}$ & $>1500$ & $-1.0 \pm 0.1$ & $34.91 \pm 0.01$ & $0.50 \pm 0.03$ & $36 \pm 3$ & $56.0 \pm 5$ & Null & $6.4 \pm 0.8$ & $20.9 \pm 1.1$ & $4.1 \pm 1.2$ & $11.3 \pm 0.5$ \\
\hline upper DWBC & $24^{\circ} \mathrm{N}$ & $50^{\circ} \mathrm{W}-80^{\circ} \mathrm{W}$ & $1200-2200$ & $4.1 \pm 0.6$ & $35.02 \pm 0.04$ & $0.25 \pm 0.17$ & $38 \pm 7$ & $61.2 \pm 10$ & $21.9 \pm 0.5$ & $16.5 \pm 0.4$ & $22.1 \pm 0.4$ & $21.0 \pm 0.5$ & $10.9 \pm 0.4$ \\
\hline lower DWBC & $24^{\circ} \mathrm{N}$ & $60^{\circ} \mathrm{W}-80^{\circ} \mathrm{W}$ & $3200-4200$ & $2.1 \pm 0.1$ & $34.91 \pm 0.01$ & $0.21 \pm 0.10$ & $39 \pm 5$ & $57.7 \pm 4$ & $6.0 \pm 0.6$ & $11.1 \pm 0.5$ & $17.3 \pm 0.5$ & $9.9 \pm 1.0$ & $9.6 \pm 0.3$ \\
\hline
\end{tabular}

the increase of atmospheric $\mathrm{CO}_{2}$ (Chen and Millero, 1979; Goyet et al., 1999), i.e. $\mathrm{A}_{\mathrm{T}}^{\circ}=\mathrm{A}_{\mathrm{T}}$; and that $\mathrm{O}_{2}^{\circ} \approx \mathrm{O}_{2}$. The equation for the reference term $\operatorname{TrOCA}^{\circ}$ is a function of $\theta$ and $\mathrm{A}_{\mathrm{T}}$. This equation is derived from $\Delta^{14} \mathrm{C}$ and corresponding to water parcels that can be assumed to be free of $\mathrm{C}_{\mathrm{ant}}$. When the concentration of $\Delta{ }^{14} \mathrm{C}<175$ per mille, the approximate age of the corresponding water mass is greater than 1400 years, long before the beginning of human $\mathrm{CO}_{2}$ massive emissions. The samples with maximum CFC11 concentrations, typically between 262.9 and 271.3 pptv corresponding to surface waters in 1992-1995 (maximum atmospheric $p$ CFC11), were also selected as part of the dataset to obtain the $\mathrm{TrOCA}^{\circ}$ expression.

\section{Results and discussion}

\subsection{Anthropogenic $\mathrm{CO}_{2}$ distributions}

The meridional distributions of $\mathrm{C}_{\mathrm{ant}}$ calculated from the $\Delta \mathrm{C}^{*}, \varphi \mathrm{C}_{\mathrm{T}}^{\circ}, \mathrm{C}_{\mathrm{IPSL}}^{\circ}$, TrOCA and TTD methods are shown in Fig. 1d-h, respectively. The spatial patterns are similar in all calculations. The maximum $\mathrm{C}_{\mathrm{ant}}$ values (40$\left.60 \mu \mathrm{mol} \mathrm{kg}^{-1}\right)$ are consistently located in the northern subtropical gyre $\left(20^{\circ} \mathrm{N}, 50^{\circ} \mathrm{N}\right)$, where the intensification of the Meridional Overturning Circulation (MOC) also provokes the strongest water mass outcrops and deepest $\mathrm{C}_{\mathrm{ant}}$ transport. Alternatively, $\mathrm{C}_{\mathrm{ant}}$ minima are unanimously located under the southern subtropical gyre below $1500 \mathrm{~m}$, where the oldest water masses are found in the Atlantic eastern basin (Fig. 1b). There is also general agreement in the area of largest $C_{a n t}$ gradients, just above the $15 \mu \mathrm{mol} \mathrm{kg}^{-1}$ isopleth. The strong water mass formation processes in the North Atlantic subpolar gyre (Schmitz, 1996) have a large effect on the dynamics of $\mathrm{C}_{\mathrm{ant}}$ oceanic uptake. They provoke the different $C_{a n t}$ distributions observed in the Nordic Seas, where the $15 \mu \mathrm{mol} \mathrm{kg}^{-1}$ isoline shallows abruptly.

The results for the WOCE AR01 cruise (Fig. 2) show a similar degree of agreement to the meridional section just described. There are three distinctive features to the AR01 section: a) the upper $1000 \mathrm{~m}$ are characterised by a strong vertical $C_{\text {ant }}$ gradient, from 60 to $20 \mu \mathrm{mol} \mathrm{kg}^{-1}$; b) the minimum values $\left(0-15 \mu \mathrm{mol} \mathrm{kg}^{-1}\right)$ are consistently located in the eastern Atlantic Basin; c) the entrainment eastwards of the Deep Western Boundary Current (DWBC) upper limb is detected unanimously around $1500 \mathrm{~m}$, whereas its lower limb $\left(3000-4000 \mathrm{~m}\right.$ ) is not always as clearly seen in the $C_{\text {ant }}$ fields.

In spite of the similarities in the large-scale $\mathrm{C}_{\text {ant }}$ distributions, there are some significant variations at a regional scale, most notably in the Antarctic Bottom Water (AABW) and the Nordic Seas. Below we discuss in more detail the distributions in several different regions, shown as boxes in Figs. $1 b$ and $2 b$ (see also Table 1). For each region, the average values of several quantities are listed in Table 1, and the average $\mathrm{C}_{\mathrm{ant}}$ concentration is plotted against $p \mathrm{CFC} 12$ in Fig. 3. Whenever two or more results from different methods are compared within a region, a hypothesis contrast is applied with confidence level $\alpha=0.05$, considering the number of data $(\mathrm{N})$ and using the population means of the standard errors of the mean $(\sigma / \sqrt{\mathrm{N}})$. Vertical profiles of average $\mathrm{C}_{\mathrm{ant}}$ concentrations for the latitudes or longitudes covered by the above regions are also shown in Fig. 4 (note that several of these profiles include two of the boxed regions shown in Figs. $1 b$ and $2 b$ ).

To examine the differences between the various $\mathrm{C}_{\mathrm{ant}}$ estimates we calculate statistics between all pairs of methods. Specifically we calculate the Root Mean Square Difference (RMSD), Pearson's product-moment correlation coefficient $(R)$ and the ratio of variances $(\gamma)$. These three statistics are used to form Taylor diagrams (Taylor, 2001), which are often used to compare models with data. The RMSD can be interpreted as the magnitude of variability of one method compared to the other one in each pair, similarly to what the standard deviation represents around the mean of a given data distribution. These statistics for each region are shown graphically in Fig. 5. These plots show large variations in the statistical quantities, with cases where two estimates agree 


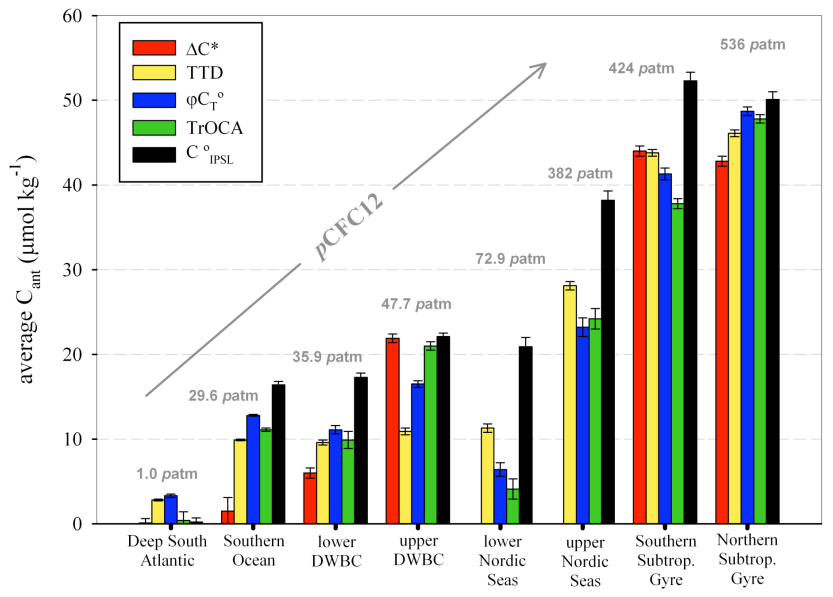

Fig. 3. Average regional $\mathrm{C}_{\text {ant }}$ estimates $(\mu \mathrm{mol} \mathrm{kg}-1)$ predicted by the five $\mathrm{C}_{\text {ant }}$ reconstruction methods here considered plotted in increasing order of average $p \mathrm{CFC} 12$ (patm) concentration on the studied regions. Notice that the $p \mathrm{CFC} 12$ scale is nominal and therefore non-linear. The error bars give the standard error of the mean $( \pm \sigma / \sqrt{\mathrm{N}})$.

very well (i.e. low RMSD and $R$, and $\gamma$ near unity) as well as other ones where there are large differences. These differences are discussed in more detail below, but in general, comparisons of the TTD estimates with the other estimates yield the largest differences, i.e., the highest RMSDs, lowest $R$, and values of $\gamma$ furthest from unity. The $\varphi \mathrm{C}_{\mathrm{T}}^{\circ}$ method generally shows the opposite: it generally has the lowest RMSDs, highest $R$, and $\gamma$ values closest to unity. Interestingly, but perhaps not surprising, the carbon-based methods TrOCA, $\mathrm{C}_{\mathrm{IPSL}}^{\circ}$ and $\varphi \mathrm{C}_{\mathrm{T}}^{\circ}$ come out highly correlated independently of the region considered.

\subsubsection{Deep South Atlantic}

The oldest water masses in the Atlantic are found in deep waters around $30^{\circ} \mathrm{S}$ and they are expected to have near-zero $\mathrm{C}_{\text {ant }}$ loads (Figs. 1b, 3 and Table 1). Deeper than $2000 \mathrm{~m}$ the average $C_{\text {ant }}$ vertical profiles from all methods stabilize at very low values, however the actual values differ between methods, with $\Delta \mathrm{C}^{*}$, and $\mathrm{C}_{\mathrm{IPSL}}^{\circ}$ estimates being the lowest and TTD and $\varphi \mathrm{C}_{\mathrm{T}}^{\circ}$ the largest (Fig. 4b). Most $\Delta \mathrm{C}^{*}$ estimates for this region were either missing values or outliers and, therefore, excluded from inventory computations. In addition, the $\Delta C^{*}$ method defines its absolute zero- $C_{\text {ant }}$ at the deep, very old waters based on CFC or $\Delta^{14} \mathrm{C}$ age estimates. Analogous comments apply to the results from the $\mathrm{C}_{\text {IPSL }}^{\circ}$ method, although this method does not report as many negative or missing values as in the $\Delta C^{*}$ case. The RMSD values in this region are low for all pairs of methods, which is likely related to the low average $\mathrm{C}_{\text {ant }}$ concentrations in the very old waters. The correlation between methods is general high, with the highest $R$ for $\Delta \mathrm{C}^{*}-\varphi \mathrm{C}_{\mathrm{T}}^{\circ}$ correlation (Fig. 5).
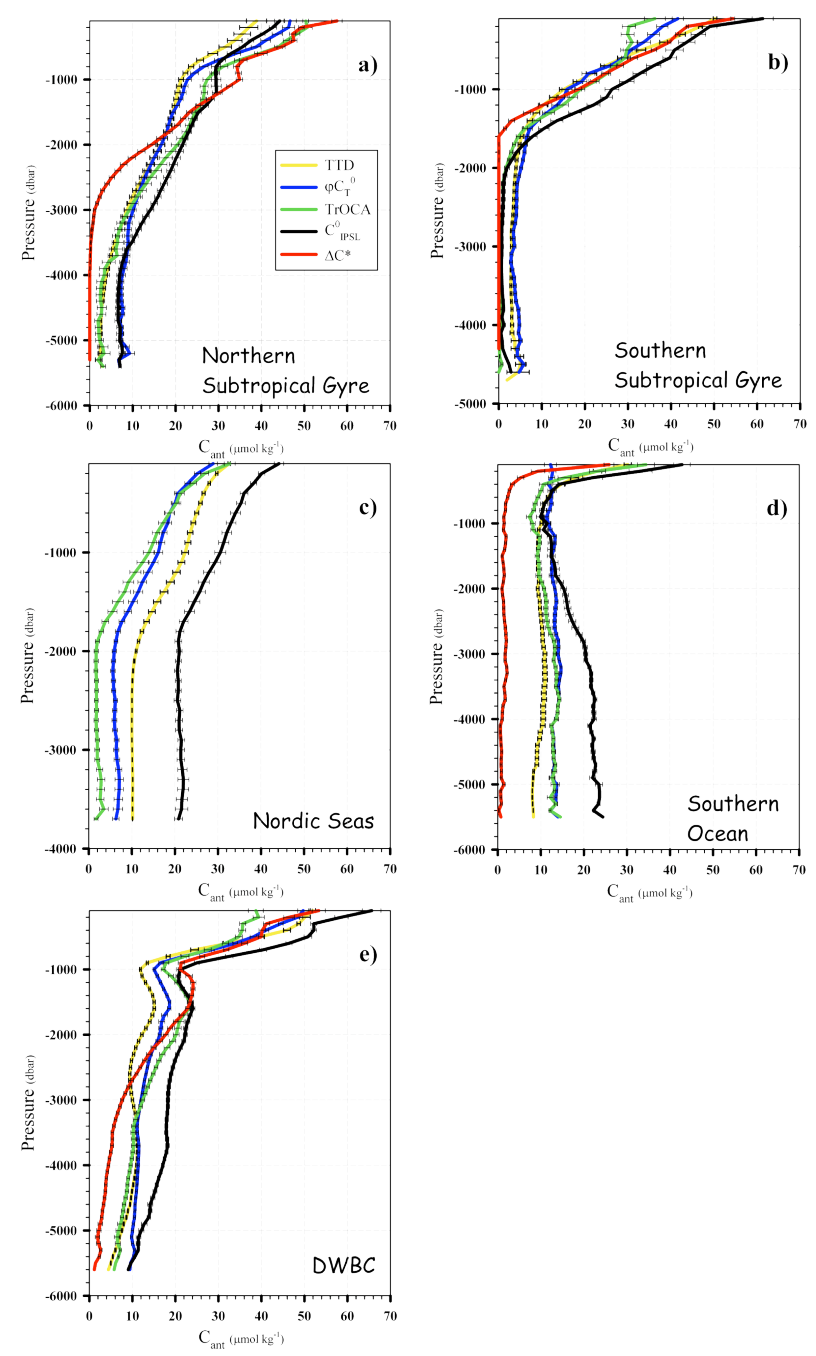

Fig. 4. Average vertical $\mathrm{C}_{\text {ant }}$ profiles $\left(\mu \mathrm{mol} \mathrm{kg}^{-1}\right)$ of the selected regions in Figs. $1 b$ and $2 b$. The $C_{a n t}$ estimates in each region were averaged over common depth intervals and the error bars represent the standard error of the mean $( \pm \sigma / \sqrt{\mathrm{N}})$.

\subsubsection{Subtropical gyres}

The northern subtropical gyre, with an observed average age of 4 years (right-hand Box 2 in Fig. 1b), contains on average the highest $\mathrm{C}_{\text {ant }}$ concentrations and $p C F C 12$ values (Fig. 3). The carbon-based methods $\mathrm{TrOCA}, \mathrm{C}_{\mathrm{IPSL}}^{\circ}$ and $\varphi \mathrm{C}_{\mathrm{T}}^{\circ}$ are all found to be significantly higher ( $\mathrm{p}$-level $>0.995$ in all cases) than the TTD estimate. The effect that the biology of the region could introduce via the $R_{\mathrm{C}}$ ratio is likely to have a minimum impact on results from the carbon-based methods, given the low apparent oxygen utilisation (AOU) average values. This makes the biological contribution an improbable source to this difference between TTD and carbon-based methods. Contradictorily, the average from the $\Delta C^{*}$ method, which is also carbon-based, is significantly lower than the 

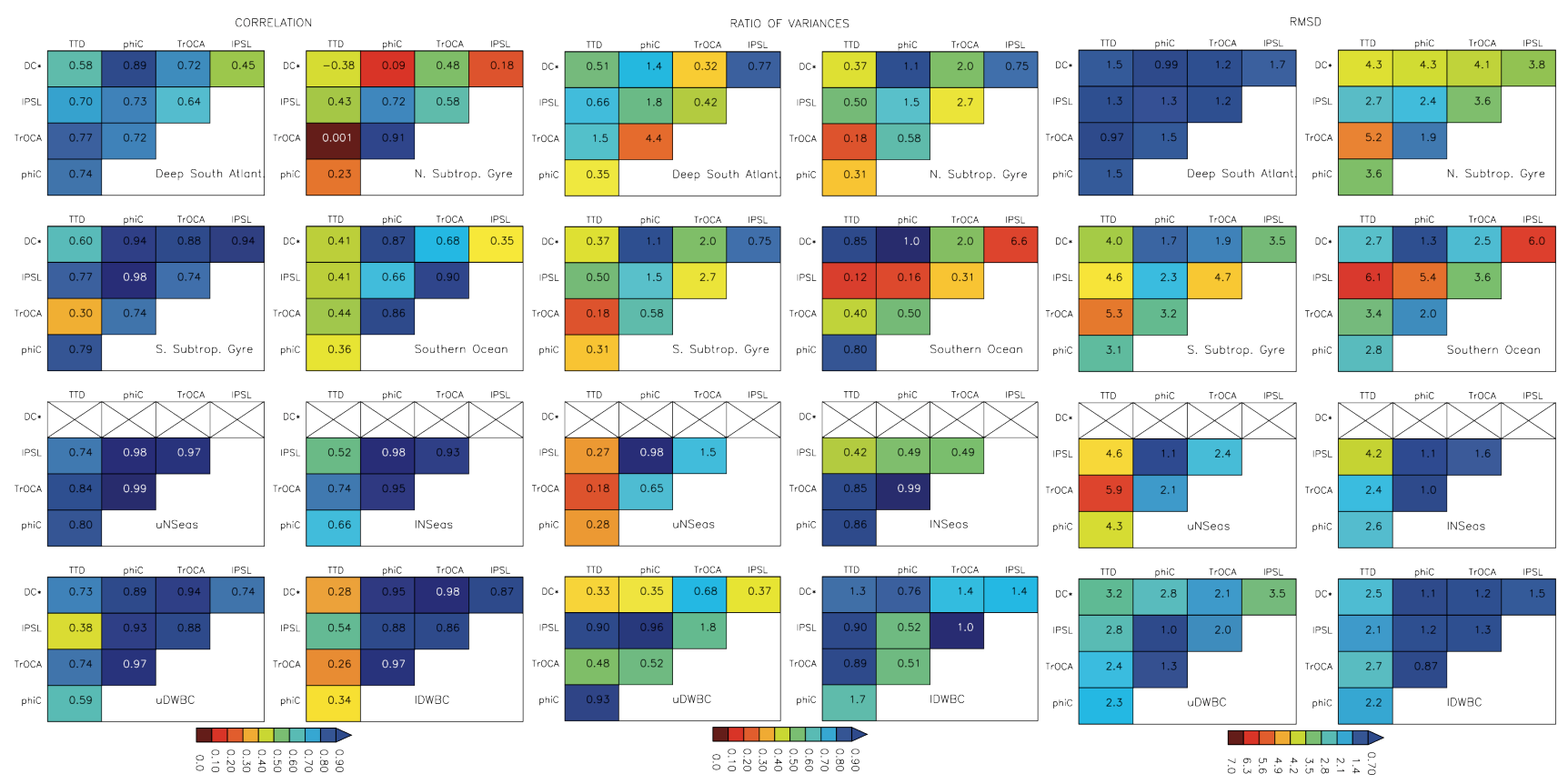

Fig. 5. Array of statistics for each of the regions highlighted in Figs. $1 \mathrm{~b}$ and $2 \mathrm{~b}$. The Pearson's product-moment correlation coefficient $(R)$, Root Mean Square Difference (RMSD, in $\mu \mathrm{mol} \mathrm{kg}^{-1}$ ) and ratio of variances $(\gamma)$ were calculated for all method pairs. In all cases the more bluish the colour the better the agreement (dark blue for $R= \pm 1, \mathrm{RMSD}=0$, and $\gamma=1$ ). For the ratio of variances, $\gamma$ and $1 / \gamma$ are the same colour. Here, $\mathrm{RMSD}=\sqrt{1 / \mathrm{N} \sum_{i=1}^{\mathrm{N}}\left[\left(\mathrm{A}_{i}-\overline{\mathrm{A}}\right)-\left(\mathrm{B}_{i}-\overline{\mathrm{B}}\right)\right]^{2}}$, where $\mathrm{A}_{i}$ is the $i$-th $\mathrm{C}_{\text {ant }}$ estimate of the considered method "A" in the comparison pair, and " $\overline{\mathrm{A}}$ " is the average of the subset of estimates considered from method "A". The terms $\mathrm{B}_{i}$ and " $\overline{\mathrm{B}}$ " are analogously defined for method "B". N stands for the number of valid A-B data pairs.

TTD value by $3.3 \mu \mathrm{mol} \mathrm{kg}^{-1}$ (Fig. 3 and Table 1). The $\mathrm{C}_{\mathrm{ant}}$ estimates in the southern subtropical gyre are similar to the northern counterpart, but with slightly lower average $C_{a n t}$ concentrations and less $\mathrm{C}_{\text {ant }}$ entrainment into the ocean interior (Fig. $4 \mathrm{~b}$ and c). The above-described differences translate into different vertical $\mathrm{C}_{\text {ant }}$ gradients. In the southern subtropical gyre the $\mathrm{C}_{\mathrm{IPSL}}^{\circ}$ and $\Delta \mathrm{C}^{*}$ have stronger vertical $\mathrm{C}_{\mathrm{ant}}$ gradients than the rest of methods (Fig. 4b). This same pattern is observed in the northern subtropical gyre but it does not appear to be so clear due to the larger penetrations of $\mathrm{C}_{\mathrm{ant}}$ in the water column (Fig. 4c). Lastly, it is worth noting from Figs. $1 \mathrm{~d}-\mathrm{h}$ and $4 \mathrm{c}$ that all methods detect the Mediterranean water (MW) influence, which causes a relative maximum of $\mathrm{C}_{\text {ant }}$ (average $22.6 \pm 3.5 \mu \mathrm{mol} \mathrm{kg}^{-1}$ ) at about $1100 \mathrm{~m}$ depth at $37^{\circ} \mathrm{N}$ (Ríos et al., 2001; Álvarez et al., 2005; Ait-Ameur and Goyet, 2006). Large RMSDs are found for both subtropical gyres, and there is also a generalised tendency towards low correlation values. The most extreme values occur in the northern gyre, where there are generally very large RMSD and very low correlations between TTD and $\Delta \mathrm{C}^{*}$ and the other methods, and between TTD and $\Delta \mathrm{C}^{*}$. In fact, out of all the studied regions and method pairs considered, the case of the TTD and $\Delta \mathrm{C}^{*}$ in the northern subtropical gyre is the only where two methods have yielded $\mathrm{C}_{\text {ant }}$ estimates that are inversely correlated.

\subsubsection{The Nordic Seas}

Only four methods are compared in the Nordic Seas, as the GLODAP dataset (i.e., the $\Delta \mathrm{C}^{*}$ method) did not include the 2005 NSeas-Knorr data used in this study. This region is characterised by moderate $p \mathrm{CFC} 12$ values (Fig. 3) and two well-defined layers in terms of $\mathrm{C}_{\mathrm{ant}}$ with rather homogeneous concentrations (Figs. 1d-h and $4 d$ ). In the upper layer (100-750 m, upper Box 4 in Fig. 1b), the $C_{\text {IPSL }}^{\circ}$ approach gives the highest estimate $\left(38.2 \pm 1.1 \mu \mathrm{mol} \mathrm{kg}{ }^{-1}\right)$ followed by the TTD $\left(28.1 \pm 0.5 \mu \mathrm{mol} \mathrm{kg}^{-1}\right)$, while the TrOCA and $\varphi \mathbf{C}_{\mathrm{T}}^{\circ}$ methods give lower and similar values $(24.2 \pm 1.4$ and $23.2 \pm 1.1 \mu \mathrm{mol} \mathrm{kg}{ }^{-1}$, respectively). In the lower Nordic Seas $(1500 \mathrm{~m}$ to bottom, lower Box 4 in Fig. 1b), all four methods produced different results and the discrepancies are larger than in the upper region (Figs. 3 and 4c): estimates from the TrOCA $\left(4.1 \pm 1.2 \mu \mathrm{mol} \mathrm{kg}^{-1}\right)$ and the $\varphi \mathrm{C}_{\mathrm{T}}^{\circ}$ $\left(6.4 \pm 0.8 \mu \mathrm{mol} \times \mathrm{kg}^{-1}\right)$ approaches are statistically lower, almost by half, than the TTD results. The $\mathrm{C}_{\mathrm{IPSL}}^{\circ}$ method gives the maximum $\mathrm{C}_{\text {ant }}$ estimate $(20.9 \pm 1.1 \mu \mathrm{mol} \mathrm{kg}-1)$, almost twice as large as the TTD method average value $\left(11.3 \pm 0.5 \mu \mathrm{mol} \mathrm{kg}{ }^{-1}\right)$, i.e., about the same trend of discrepancies observed in the deep Southern Ocean. The RMSDs cluster around a value of $\sim 1.5 \mu \mathrm{mol} \mathrm{kg}^{-1}$ except in the case of the TTD comparison pairs, where the RMSD is as large 
as $5.9 \mu \mathrm{mol} \mathrm{kg}^{-1}$ (TTD-TrOCA). This gives an idea of how variable the average vertical $C_{a n t}$ profiles are with respect to the TTD, especially in the upper Nordic Seas. Nevertheless, the TTD vertical profile (Fig. 4c) represents quite the average of all methods in this region, most importantly in the lower Nordic Seas, and this is somewhat reflected by the associated $R$ and $\gamma$ values. The lowest $\gamma$ for this region correspond to all method pairs involving the TTD $(\gamma \sim 0.22)$ and IPSL $(\gamma \sim 0.47)$ methods in the upper and lower Nordic Seas, respectively.

\subsubsection{The Southern Ocean}

South of $50^{\circ} \mathrm{S}$ the different methods, although applied to the same dataset, present very contrasting results. The average $\mathrm{C}_{\mathrm{ant}}$ vertical profiles (Fig. 4d) share similar patterns: moderate values in the first $500 \mathrm{~m}$ before they suddenly drop into a plateau of almost constant concentrations in the rest of the water column. This trend is slightly different for $\mathrm{C}_{\mathrm{IPSL}}^{\circ}$ and $\varphi \mathrm{C}_{\mathrm{T}}^{\circ}$. For the former there is a tendency of $\mathrm{C}_{\text {ant }}$ to increase with depths below $1000 \mathrm{~m}$, while the latter has a very stable vertical profile centred at $\sim 12.5 \mu \mathrm{mol} \mathrm{kg}^{-1}$. The AABW forms in this region from Circumpolar Deep Water (CDW) and Ice Shelf Waters (ISW), potentially driving in the Southern Ocean an intense conveyance of $\mathrm{C}_{\mathrm{ant}}$ down to the seafloor $(>5000 \mathrm{~m})$. The fact that $\mathrm{C}_{\mathrm{ant}}$ may have penetrated this far down in the Southern Ocean is also suggested by the presence of CFC12 in the water column (Box 3 in Fig. 1b and Fig. 3). Consequently, the TTD method (based mainly on CFC12 data) produced $\mathrm{C}_{\text {ant }}$ down to the bottom at high latitudes, a signal that was not captured in the $\Delta \mathrm{C}^{*}$ results (Figs. 3 and 4d) (Lo Monaco et al., 2005a, b; Waugh et al., 2006). Interestingly, the other methods (TrOCA, $\mathrm{C}_{\mathrm{IPSL}}^{\circ}$ and $\varphi \mathrm{C}_{\mathrm{T}}^{\circ}$ ) also detected significant $\mathrm{C}_{\mathrm{ant}}$ concentrations in the deep and bottom waters of the Southern Ocean. The TTD, $\varphi \mathrm{C}_{\mathrm{T}}^{\circ}$ and TrOCA methods have very similar vertical $\mathrm{C}_{\text {ant }}$ profiles below $1000 \mathrm{~m}$ (Fig. 4d). The $\Delta \mathrm{C}^{*}$ predictions give close-tozero $\mathrm{C}_{\text {ant }}$ values $\left(1.5 \pm 1.6 \mu \mathrm{mol} \mathrm{kg}^{-1}\right)$ and are clearly lower than other estimates. The $\Delta \mathrm{C}^{*}$ method assigns by default $\mathrm{C}_{\mathrm{ant}}=0$ references to old waters with low CFC concentrations, like those found below $500 \mathrm{~m}$ depths in the neighbouring regions of the South Atlantic (Gruber et al., 1996). Also, the $\Delta \mathrm{C}^{*}$ approach assumes oxygen saturation in surface waters. The low results obtained in this area could follow from this assumption (Lo Monaco et al., 2005a). Nevertheless, it must be noted that authors like Sabine et al. (2002), by applying the $\Delta C^{*}$ method in other sectors of the Southern Ocean, have obtained higher $\mathrm{C}_{\mathrm{ant}}$ estimates. The fact that the Southern Ocean is a large volume of water means that small differences between methods will ultimately translate in significant inventory differences in this region (Lo Monaco et al., 2005b). In terms of statistics, the largest RMSD values of all regions are found in this region, and there are also low correlation coefficients and $\gamma$ far from unity, indicating how disparate are the $\mathrm{C}_{\mathrm{ant}}$ estimates in this region.

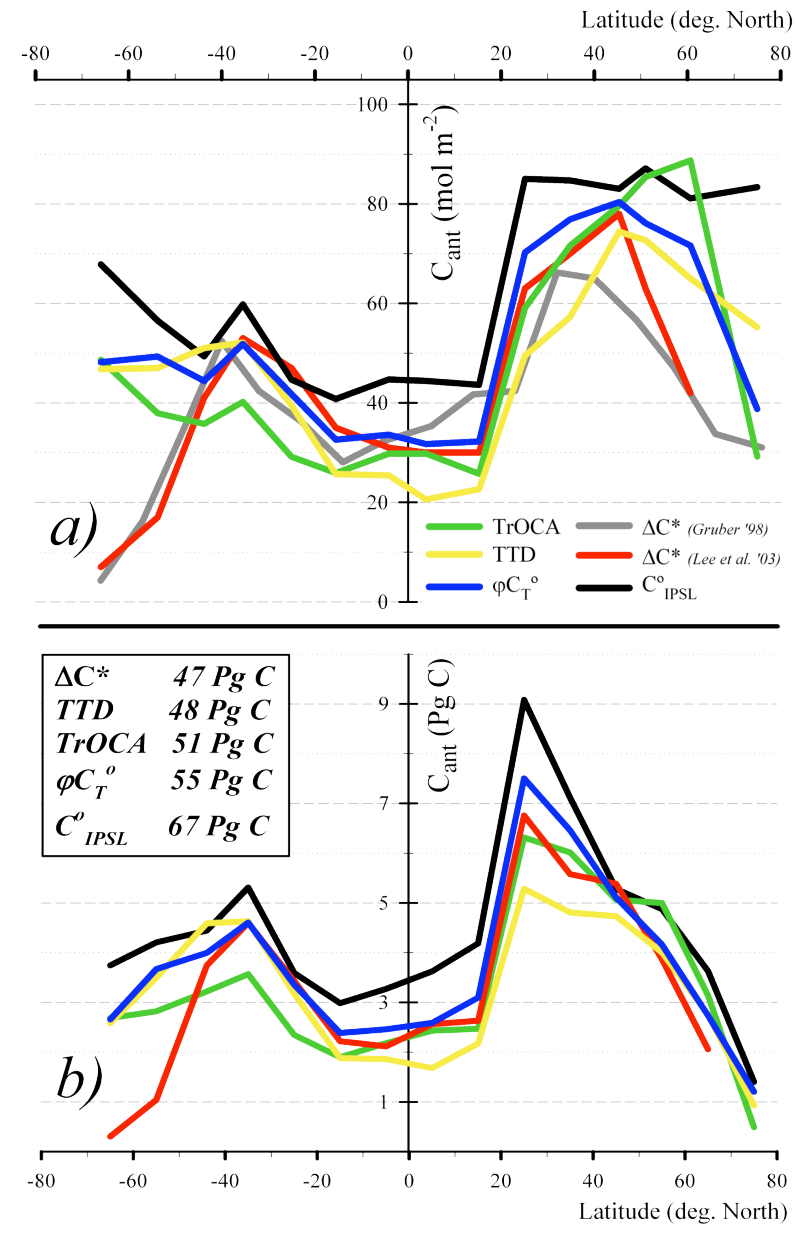

Fig. 6. Specific inventories (a) in $\mathrm{mol} \mathrm{m}^{-2}$ for the whole Atlantic computed in latitude bands every $10^{\circ}$, after Lee et al., 2003. The total inventories $(\mathrm{PgC})$ for the same domain and latitude band resolution are plotted in (b). The inlayed box gives the integrals of the presented total inventories $(\mathrm{PgC})$ for each method in the Atlantic Ocean.

\subsubsection{The Deep Western Boundary Current (DWBC)}

The DWBC is detected in $\mathrm{C}_{\text {ant }}$ from all methods (Fig. 2b). However, there are differences in the intensity of the vertical $\mathrm{C}_{\mathrm{ant}}$ gradient generated by the upper limb $(u \mathrm{DWBC})$, centred around $1500 \mathrm{~m}$, and the lower limb (lDWBC), centred around $3500 \mathrm{~m}$. The clearest signal in the DWBC is given by the $\mathrm{C}_{\mathrm{IPSL}}^{\circ}$ method, whilst the signal from the TTD approach is the weakest in terms of eastward penetration and vertical gradient between the two limbs (Figs. 3 and 4e). The TrOCA and $\Delta \mathrm{C}^{*}$ methods display the largest gradient between limbs (Fig. 4e). However, when we compared the signal from the eastward $l \mathrm{DWBC}$ entrainment in both methods the TrOCA showed a well-defined limb, while the $\Delta C^{*}$ one was almost imperceptible. The $\varphi \mathbf{C}_{\mathrm{T}}^{\circ}$ method gives values that are in the middle of the range from all methods (Table 1). Otherwise, it yields a weak $l$ DWBC signal that is reproduced slightly 
deeper than in the rest of methods. Finally, it is also notable that the eastward deflection and propagation of the North Atlantic Deep Water upper limb ( $u$ NADW) coming from the $u$ DWBC (Weiss et al., 1985; Andrié et al., 1998) can also be observed in Fig. 1: a $\mathrm{C}_{\text {ant }}$ maximum located at $1500-2000 \mathrm{~m}$ depth in the Equator corresponding with a relative minimum of CFC12 age ( $\sim 50 \mathrm{yr})$ is detected to different extents by all methods. There are low RMSDs between most pairs of methods for both limbs. The methods are generally highly correlated and have similar variances. The TTD method is the exception with regard to the correlations, and there are low correlations between the TTD and other methods in the lDWBC.

\subsection{Atlantic inventories of anthropogenic $\mathrm{CO}_{2}$}

To assess how the previous differences in the various databased $\mathrm{C}_{\text {ant }}$ estimates affect the global $\mathrm{C}_{\text {ant }}$ budget, the results were integrated on the Atlantic basin scale. In calculating the inventory the following considerations were made: a) the water column integrals were calculated over the same 10-degree wide latitude bands as in Lee et al. (2003). In so doing, the results obtained can be compared with their estimates from the $\Delta C^{*}$ method; b) no in situ surface $C_{\text {ant }}$ estimates were used at all so as to avoid the seasonal biogeochemical variability from surface layer data. Instead, values from the bottom limit of the winter mixed-layer were extended to $0 \mathrm{~m}$, so that $\mathrm{C}_{\text {ant }}$ from surface waters is still being considered in inventory calculations (Lo Monaco et al., 2005b). On the basis of winter mixed layer depths the location of the bottom limits were placed at $100 \mathrm{~m}$ in subtropical and equatorial waters, and at $300 \mathrm{~m}$ for waters in the $\left(33^{\circ} \mathrm{S}-50^{\circ} \mathrm{S}\right)$ latitude band; c) regarding total inventories, the meridional cruises used in this study belong to the eastern Atlantic basin. To tackle the zonal asymmetry assumption, results in Table 5 from Lee et al., 2003 were used. They provided specific inventories $\left(\mathrm{mol} \mathrm{m}^{-2}\right)$ for the eastern and western basins and the total inventories $(\mathrm{PgC})$ for different latitude bands. A conversion factor per band of latitude $(1.04 \pm 0.10)$ that accounted for the area was calculated using the eastern basin specific inventory and the total inventory data from Lee et al., 2003. Given the similarities here found in the general $\mathrm{C}_{\text {ant }}$ distributions it is assumed that the scaling obtained for the $\Delta C^{*}$ from Lee et al. (2003) can be applied to the rest of methods. Knowingly of the caveats attached to this practice, this assumption allows to calculate Atlantic inventories from the presented eastern Atlantic basin results; d) the $\mathrm{C}_{\text {ant }}$ inventories from Gruber (1998) and Lee et al. (2003) are included in Fig. 6a to show how the $\Delta C^{*}$ method yields very low values in the Southern Ocean, regardless of the dataset to which it is applied (Lo Monaco et al., 2005a). These inventories were calculated from different data collected over the same region here studied, and were referenced to year 1994; e) The errors for the specific inventories are of $\pm 1 \mathrm{~mol} \mathrm{~m}^{-2}$ or $\pm 2 \mathrm{~mol} \mathrm{~m}^{-2}$ when integrated down to $3000 \mathrm{~m}$ or $6000 \mathrm{~m}$, re- spectively. They were calculated by means of random propagation of a $5 \mu \mathrm{mol} \mathrm{kg}^{-1}$ standard error of the Cant estimate with depth. Error bars in Fig. 6a are omitted for clarity.

All methods give reasonably similar specific inventories (Fig. 6a), except for the $\Delta C^{*}$ method in the Southern Ocean from either Gruber (1998) or Lee et al. (2003). The greatest similarities occur in the subtropical and equatorial regions, while some discrepancies between the $\mathrm{C}_{\mathrm{IPSL}}^{\circ}, \varphi \mathrm{C}_{\mathrm{T}}^{\circ}$, TrOCA and TTD methods appear towards higher latitudes, especially north from $55^{\circ} \mathrm{N}$, where none of the estimates converge. In the Southern Ocean (south of $55^{\circ} \mathrm{S}$ ), the $\Delta \mathrm{C}^{*}$ method shows extremely low values $\left(10 \pm 5 \mathrm{~mol} \mathrm{~m}^{-2}\right.$ on average) considering the non-negligible amount of CFCs found in this basin (Fig. 1b). These estimates are five to seven times lower than any other result in this area. The strong decreasing trend of the specific inventories according to the $\Delta C^{*}$ approach is also opposite to the other carbon-based methods which describe increasing specific inventories south from $45^{\circ} \mathrm{S}$. More substantial differences were identified in other regions: in the Tropics, the TTD method gives about half the amount of $\mathrm{C}_{\mathrm{an}}$ the $\mathrm{C}_{\text {IPSL }}^{\circ}$ method does, and in the North Atlantic differences of $20 \mathrm{~mol} \mathrm{~m}^{-2}$ are common.

The specific inventories were integrated by area to calculate the total inventories (in $\mathrm{PgC}$ ) over the same bands of latitude (Fig. 6b). In so doing, the aforementioned differences in the Nordic Seas diminish. All methods display an "M-shape" in the total inventory distribution, with a coherent maximum around $20-30^{\circ} \mathrm{N}$ and a relative maximum at $40-50^{\circ} \mathrm{S}$. Although significant differences can still be seen between methods, we believe that the "M-shape" describes faithfully oceanic anthropogenic $\mathrm{CO}_{2}$ fields and should be reproduced by ocean and climate models. The total inventories for the Atlantic basin (excluding the Nordic Seas), referred to 1994 estimated by the $\mathrm{C}_{\mathrm{IPSL}}^{\circ}, \varphi \mathrm{C}_{\mathrm{T}}^{\circ}$, TrOCA and TTD methods are: $67,55,51$ and $48 \mathrm{Pg} \mathrm{C}$, respectively (average $55 \pm 8 \mathrm{Pg} \mathrm{C}$; Fig. $6 \mathrm{~b}$ ). These results are higher than the $47 \mathrm{Pg} \mathrm{C}$ inventory given by Lee et al. (2003) using the $\Delta \mathrm{C}^{*}$ approach, and if this $\Delta C^{*}$ estimate is to be included then the average $\mathrm{C}_{\mathrm{ant}}$ inventory estimate for the Atlantic would drop to $54 \pm 8 \mathrm{Pg} \mathrm{C}$. The main reason for the low inventory from the $\Delta C^{*}$ method comes mainly from the low $\mathrm{C}_{\text {ant }}$ concentrations predicted in the Southern Ocean (Fig. 1d), which alone represents $11-12 \%$ of the total inventory. The average $C_{a n t}$ inventories for the North and South Atlantic, considering all five methods, are $32 \pm 4$ and $22 \pm 5 \mathrm{Pg} \mathrm{C}$, respectively.

\subsection{Discussion}

The differences in the total inventories are mainly due to differences obtained for waters under the $5^{\circ} \mathrm{C}$ isotherm (Fig. 1c), which separates $\sim 86 \%$ of the Atlantic volume (excluding marginal seas) and divides the $\mathrm{C}_{\text {ant }}$ inventory by approximately half. This means that small errors in the estimation of $\mathrm{C}_{\text {ant }}$ have larger impacts in the inventories when they occur in $\theta<5^{\circ} \mathrm{C}$ waters. Some of the differences in these 
waters can be linked to assumptions in the methods. For instance, the high estimates obtained with the $\mathrm{C}_{\mathrm{IPSL}}^{\circ}$ method in the Southern Hemisphere likely come from having overestimated the oxygen undersaturation in Antarctic surface waters, which would lead to $\mathrm{C}_{\text {ant }}$ overestimates (Lo Monaco et al., 2005a). For the TrOCA method low inventory estimates were identified in the South Atlantic (Fig. 6b). These are likely to derive from the large amount of close-to-zero $\mathrm{C}_{\mathrm{ant}}$ estimates in the deep waters from the South Atlantic (Fig. 1g). The TTD method gives the lowest total inventory in the North Atlantic. This approach assumes the global constant $\Delta / \Gamma=1$ and this constraint might not be representative of the North Atlantic (Steinfeldt et al., 2008). Here, the influence of the MOC makes advection gain importance over the mixing processes. Finally, the $\varphi \mathbf{C}_{\mathrm{T}}^{\circ}$ method lacks extreme values at virtually any of the studied regions, although slightly low values are found in the upper $1000 \mathrm{~m}$ of the Nordic Seas. Also, it would be desirable that this method incorporated a more robust and complex OMP to resolve the water mass mixing in the Atlantic.

The assumptions made by the methodologies suggest that the causes for the disagreements may be due to: a) ice cap hindering of ventilation processes that alter the source properties of the water masses; b) the Alkalinity signal from the Arctic rivers is very different to the other waters of the world ocean; c) surface layer observations are normally used to parameterize properties, like preformed $\mathrm{A}_{\mathrm{T}}\left(\mathrm{A}_{\mathrm{T}}^{\circ}\right.$, i.e., $\mathrm{A}_{\mathrm{T}}$ when the water mass outcrops) or air-sea $\mathrm{CO}_{2}$ disequilibrium $\left(\Delta \mathrm{C}_{\mathrm{dis}}\right)$, that are later conveyed to the underlying isopycnals. The climate change driven shift of surface thermohaline characteristics would force the parameterizations to propagate wrong values towards the deeper ends of isopycnals, which have not sensed this thermal alteration yet. d) The North Atlantic Central Water (NACW) enters the surface North Atlantic and Norwegian Atlantic Current Systems with higher loads of anthropogenic $\mathrm{CO}_{2}$ than they did in the past. This process causes the $\Delta \mathrm{C}_{\mathrm{dis}}$ driving $\mathrm{C}_{\text {ant }}$ uptake to diminish (Olsen et al., 2006). These factors introduce biases in the equations used to calculate $C_{\text {ant }}$.

In spite of the general convergence of the methods considered the choice of one data-based approach or another really depends on the region of interest, given the local variability of the results (Table 1, Fig. 6). Future revisions of the methods should focus on improving $\mathrm{C}_{\text {ant }}$ estimates in the Southern Ocean and Nordic Seas. These areas seem to be a determining issue in the discrepancies found for anthropogenic $\mathrm{CO}_{2}$ burdens. The approximations of constant $R_{\mathrm{C}}$ ratios made by all carbon-based methods and the same relative weight given to advection and mixing $(\Delta / \Gamma=1$, Waugh et al., 2006) at a global scale by the TTD method need to be relaxed. Finally, all methods involving water mass mixing calculations in their algorithms should strive to improve their own implementation of the intricate mixing issues in strong water mass formation regions, particularly in the northern Subpolar Gyre and Nordic Seas.

\section{Conclusions}

Five data-based methods (the TTD, $\Delta \mathrm{C}^{*}$, TrOCA, $\mathrm{C}_{\mathrm{IPSL}}^{\circ}$ and $\varphi \mathrm{C}_{\mathrm{T}}^{\circ}$ ) have been applied to a high-quality dataset to produce estimates of the $\mathrm{C}_{\mathrm{ant}}$ distribution and inventory for the full length of the Atlantic Ocean. The differences between $\mathrm{C}_{\text {ant }}$ estimates are small in the Subtropics but larger for polar regions. The impact of these differences is most important in the Southern Ocean given its large contribution (up to 12\%) to the total inventory of $\mathrm{C}_{\mathrm{ant}}$. The average $\mathrm{C}_{\mathrm{ant}}$ Atlantic inventory of $54 \pm 8 \mathrm{PgC}$ here obtained from the five methods suggests that previous estimates given by Gruber (1998) and Lee et al. (2003) could be underestimated. These differences in observational estimates should be considered in modeldata comparisons. Furthermore, in addition to basin-scale comparisons, regional validation of models is encouraged as similar Atlantic inventories could result from diverse $C_{a n t}$ distributions.

It is worth noting that the large uncertainties in $\mathrm{C}_{\text {ant }}$ distributions identified in the Southern Ocean and Nordic Seas could lead to diverse scenarios and, henceforth, different conclusions regarding issues such as the carbon system saturation state and ocean acidification. Therefore, a multi databased analysis combining outputs from observational and numerical models at different scales is strongly encouraged and should be addressed in the future. The results here shown will also help to better understand the evolution of the latitudinal atmospheric $\mathrm{CO}_{2}$ gradient since the Preindustrial era, and how this is associated with the meridional transports of $\mathrm{C}_{\mathrm{T}}$ on the long-time scale.

Acknowledgements. We would like to extend our gratitude to the Chief Scientists, scientists and crew who participated and put their effort in the oceanographic cruises utilized in this study, particularly to those responsible for the carbon, CFC, and nutrients measurements. The comments from two anonymous reviewers have been very valuable and constructive, and have greatly helped improving this work. This work was developed and funded by the European Commission within the 6th Framework Programme (EU FP6 CARBOOCEAN Integrated Project, Contract no. 511176). Marcos Vázquez-Rodríguez is funded by Consejo Superior de Investigaciones Científicas (CSIC) I3P predoctoral grant program REF. I3P-BPD2005.

Edited by: A. Bricaud

\section{References}

Aït-Ameur, N. and Goyet, C.: Distribution and transport of natural and anthropogenic $\mathrm{CO}_{2}$ in the Gulf of Cadiz, Deep-Sea Res. II, 53, 1329-1343, 2006.

Álvarez, M., Pérez, F. F., Shoosmith, D. R., and Bryden, H. L.: The unaccounted role of Mediterranean Water in the drawdown of anthropogenic carbon, J. Geophys. Res., 110, 1-18. doi:10.1029/2004JC002633, 2005. 
Anderson, L. G., Holby, O., Lindegren, R., and Ohlson, M.: The transport of anthropogenic carbon dioxide into the Weddell Sea, J. Geophys. Res., 96, 16679-16687, 1991.

Anderson, L. A. and Sarmiento, J. L.: Redfield ratios of remineralization determined by nutrient data analysis, Global Biogeochem. Cy., 8, 65-80, 1994.

Andrié, C., Ternon, J. F., Messias, M. J., Mémery, L., and Bourlès, B.: Chlorofluoromethanes distributions in the deep equatorial Atlantic during January-March 1993, Deep-Sea Res. I, 45, 903930, 1998.

Bellerby, R. G. J., Olsen, A., Furevik, T., and Anderson, L. A.: Response of the surface ocean $\mathrm{CO}_{2}$ system in the Nordic Seas and North Atlantic to climate change, in: Climate Variability in the Nordic Seas, edited by: Drange, H., Dokken, T. M., Furevik, T., Gerdes, R., and Berger, W., Geophysical Monograph Series, AGU, 189-198, 2005.

Brewer, P. G.: Direct observation of the oceanic $\mathrm{CO}_{2}$ increase, Geophys. Res. Lett., 5, 997-1000, 1978.

Broecker, W. S.: "NO" a conservative water mass tracer, Earth Planet. Sci. Lett., 23, 8761-8776, 1974.

Chen, C.-T. A. and Millero, F. J.: Gradual increase of oceanic $\mathrm{CO}_{2}$, Nature, 277, 205-206, 1979.

Coatanoan, C., Goyet, C., Sabine, C. L., and Warner, M.: Comparison of the two approaches to quantify anthropogenic $\mathrm{CO}_{2}$ in the ocean: results from the northern Indian, Global Biogeochem. Cy., 15, 11-26, 2001.

Feely, R. A., Sabine, C. L., Lee, K., Berelson, W., Kleypas, J., Fabry, V. J., and Millero, F. J.: Impact of Anthropogenic $\mathrm{CO}_{2}$ on the $\mathrm{CaCO}_{3}$ System in the Oceans, Science, 305, 362-366, 2004.

Friis, K.: A review of marine anthropogenic $\mathrm{CO}_{2}$ definitions: Introducing a thermodynamic approach based on observations, Tellus B, 58B, 2-15, doi:10.1111/j.1600-0889.2005.00173.x, 2006.

Gerber, M., Joos, F., Vázquez-Rodríguez, M., Touratier, F., and Goyet, C.: Regional air-sea fluxes of anthropogenic carbon inferred with an Ensemble Kalman Filter, Global Biogeochem. Cy., 23, GB1013, doi:10.1029/2008GB003247, 2009.

Gloor, M., Gruber, N., Sarmiento, J., Sabine, C. L., Feely, R. A., and Rödenbeck, C.: A first estimate of present and preindustrial air-sea $\mathrm{CO}_{2}$ flux patterns based on ocean interior carbon measurements and models, Geophys. Res. Lett., 30(1), 1010, doi:10.1029/2002GL015594, 2003.

Goyet, C., Coatanoan, C., Eischeid, G., Amaoka, T., Okuda, K., Healy, R., and Tsunogai, S.: Spatial variation of total alkalinity in the northern Indian Ocean: a novel approach for the quantification of anthropogenic $\mathrm{CO}_{2}$ in seawater, J. Mar. Res., 57, 135-163, 1999.

Gruber, N.: Anthropogenic $\mathrm{CO}_{2}$ in the Atlantic Ocean, Global Biogeochemical Cycles, 12, 165-191, 1998.

Gruber, N., Sarmiento, J. L., and Stocker, T. F.: An improved method for detecting anthropogenic $\mathrm{CO}_{2}$ in the oceans, Global Biogeochem. Cy., 10, 809-837, 1996.

Hall, T. M., Haine, T. W. N., and Waugh, D. W.: Inferring the concentration of anthropogenic carbon in the ocean from tracers, Global Biogeochem. Cy., 16(4), 1131, doi:10.1029/2001GB001835, 2002.

Heinze, C.: Simulating oceanic $\mathrm{CaCO}_{3}$ export production in the greenhouse, Geophys. Res. Lett., 31, L16308, doi:10.1029/2004GL020613, 2004.
Key, R. M., Kozyr, A., Sabine, C. L., Lee, K., Wanninkhof, R., Bullister, J. L., Feely, R. A., Millero, F. J., Mordy, C., and Peng, T.-H.: A global ocean carbon climatology: Results from Global Data Analysis Project (GLODAP), Global Biogeochem. Cy., 18, GB4031, doi:10.1029/2004GB002247, 2004.

Kieke, D., Rhein, M., Stramma, L., Smethie, W. M., Bullister, J. L., and LeBel, D. A.: Changes in the pool of Labrador Sea Water in the subpolar North Atlantic, Geophys. Res. Lett., 34, L06605, doi:10.1029/2006GL028959, 2007.

Lee, K., Choi, S.-D., Park, G.-H., Wanninkhof, R., Peng, T.-H., Key, R. M., Sabine, C. L., Feely, R. A., Bullister, J. L., Millero, F. J., and Kozyr, A.: An updated anthropogenic $\mathrm{CO}_{2}$ inventory in the Atlantic Ocean, Global Biogeochem. Cy., 17(4), 1116, doi:10.1029/2003GB002067, 2003.

Lo Monaco, C., Metzl, N., Poisson, A., Brunet, C., and Schauer, B.: Anthropogenic $\mathrm{CO}_{2}$ in the Southern Ocean: Distribution and inventory at the Indian-Atlantic boundary (World Ocean Circulation Experiment line I6), J. Geophys. Res., 110, C06010, doi:10.1029/2004JC002643, 2005a.

Lo Monaco, C., Goyet, C., Metzl, N., Poisson, A., and Touratier, F.: Distribution and inventory of anthropogenic $\mathrm{CO}_{2}$ in the Southern Ocean: Comparison of three data-based methods, J. Geophys. Res., 110, C09S02, doi:10.1029/2004JC002571, 2005b.

Matear, R. J., Wong, C. S., and Xie, L.: Can CFCs be used to determine anthropogenic $\mathrm{CO}_{2}$, Global Biogeochem. Cy., 17(1), 1013, doi:10.1029/2001GB001415, 2003.

Matsumoto, K. and Gruber, N.: How accurate is the estimation of anthropogenic carbon in the ocean? An evaluation of the $\Delta C^{*}$ method, Global Biogeochem. Cy., 19, GB3014, doi:10.1029/2004GB002397, 2005.

Mikaloff-Fletcher, S. E., Gruber, N., Jacobson, A. R., Doney, S. C., Dutkiewicz, S., Gerber, M., Follows, M., Joos, F., Lindsay, K., Menemenlis, D., Mouchet, A., Müller, S. A., and Sarmiento, J. L.: Inverse estimates of anthropogenic $\mathrm{CO}_{2}$ uptake, transport, and storage by the ocean, Global Biogeochem. Cy., 20, GB2002, doi:10.1029/2005GB002530, 2006.

Olsen, A., Omar, A. M., and Bellerby, R. G. J.: Magnitude and origin of the anthropogenic $\mathrm{CO}_{2}$ increase and ${ }^{13} \mathrm{C}$ Suess effect in the Nordic seas since 1981, Global Biogeochem. Cy., 20, GB3027, doi:10.1029/2005GB002669, 2006.

Orr, J. E., Maier-Reimer, E., Mikolajewicz, U., Monfray, P., Sarmiento, J. L., Toggweiler, J. R., Taylor, N. K., Palmer, J., Gruber, N., Sabine, C. L., LeQuéré, C., Key, R. M., and Boutin, J.: Estimates of anthropogenic carbon uptake from four threedimensional global ocean models, Global Biogeochem. Cy., 15(1), 43-60, 2001.

Orr, J. E., Fabry, V. J., Aumont, O., Bopp, L., Doney, S. C., Feely, R. A., et al.: Anthropogenic ocean acidification over the twentyfirst century and its impact on calcifying organisms, Nature, 437 7059, 681-686, ISSN 0028-0836, doi:10.1038/nature04095, 2005.

Pérez, F. F., Vázquez-Rodríguez, M., Louarn, E., Padín, X. A., Mercier, H., and Ríos, A. F.: Temporal variability of the anthropogenic $\mathrm{CO}_{2}$ storage in the Irminger Sea, Biogeosciences, 5, 1669-1679, 2008, http://www.biogeosciences.net/5/1669/2008/.

Poisson, A. and Chen, C. T. A.: Why is there little anthropogenic $\mathrm{CO}_{2}$ in Antarctic Bottom Water, Deep Sea Res. A, 34, 1255$1275,1987$. 
Ríos, A. F., Pérez, F. F., and Fraga, F.: Long term (1977-1997) measurements of carbon dioxide in the Eastern North Atlantic: evaluation of anthropogenic input, Deep-Sea Res. II, 48, 22272239, 2001.

Sabine, C. L., Feely, R. A., Gruber, N., Key, R. M., Lee, K., Bullister, J. L., Wanninkhof, R., Wong, C. S., Wallace, D. W. R., Tilbrook, B., Millero, F. J., Peng, T.-H., Kozyr, A., Ono, T., and Ríos, A. F.: The oceanic sink for anthropogenic $\mathrm{CO}_{2}$, Science, 305, 367-371, 2004.

Schmitz Jr., W. J.: On the World Ocean Circulation: Volume I, Some Global Features/North Atlantic Circulation, Woods Hole Oceanographic Institution Technical Report WHOI-96-03, 1996.

Schuster, U. and Watson, A. J.: A variable and decreasing sink for atmospheric CO2 in the North Atlantic, J. Geophys. Res., 112, C11006, doi:10.1029/2006JC003941, 2007.

Sonnerup, R. E.: On the relations among CFC derived water mass ages, Geophys. Res. Lett., 28, 1739-1742, 2001.

Steinfeldt, R., Rhein, M., Bullister, J. L., and Tanhua, T.: Inventory changes in anthropogenic carbon from 1997-2003 in the Atlantic Ocean between $20^{\circ} \mathrm{S}$ and $65^{\circ} \mathrm{N}$, Global Biogeochem. Cy., submitted, 2008

Taylor, K. E.: Summarizing multiple aspects of model performance in single diagram, J. Geophys. Res., 106(D7), 7183-7192, 2001.

Thomas, $\mathrm{H}$. and Ittekot, V.: Determination of anthropogenic $\mathrm{CO}_{2}$ in the North Atlantic Ocean using water mass ages and $\mathrm{CO}_{2}$ equilibrium chemistry, J. Mar. Sys., 27, 325-336, 2001.
Touratier, F. and Goyet, C.: Applying the new TrOCA approach to estimate the distribution of anthropogenic $\mathrm{CO}_{2}$ in the Atlantic Ocean, J. Mar. Sys., 46, 181-197, 2004.

Touratier, F., Azouzi, L., and Goyet, C.: CFC11, $\triangle 14 \mathrm{C}$ and $3 \mathrm{H}$ tracers as a means to assess anthropogenic $\mathrm{CO}_{2}$ concentrations in the ocean, Tellus B, 59B, 318-325, doi:10.1111/j.16000889.2006.00247.x, 2007.

Vázquez-Rodríguez, M., Padin, X. A., Pérez, F. F., Ríos, A. F., and Bellerby, R. G. J.: Reconstructing preformed properties and air-sea $\mathrm{CO}_{2}$ disequilibria for water masses in the Atlantic from subsurface data: An application in anthropogenic carbon determination, J. Mar. Sys., submitted, 2008.

Wallace, D. W. R.: Storage and transport of excess $\mathrm{CO}_{2}$ in the oceans: the JGOFS/WOCE global $\mathrm{CO}_{2}$ survey, in: Ocean Circulation and Climate, edited by: Siedler, G., Church, J., and Gould, J., Academic Press, San Diego, USA, 489-520, 2001.

Wanninkhof, R., Doney, S. C., Peng, T. H., Bullister, J. L., Lee, K., and Feely, R. A.: Comparison of methods to determine the anthropogenic $\mathrm{CO}_{2}$ invasion into the Atlantic Ocean, Tellus B, 51B, 511-530, 1999.

Waugh, D. W., Hall, T. M., McNeil, B. I., Key, R., and Matear, R. J.: Anthropogenic $\mathrm{CO}_{2}$ in the oceans estimated using transit time distributions, Tellus B, 58B, 376-389, doi:10.1111/j.16000889.2006.00222.x, 2006.

Weiss, R. F., Bullister, J. L., Gammon, R. H., and Warner, M. J.: Atmospheric chlorofluoromethanes in the deep equatorial Atlantic, Nature, 314, 608-610, 1985. 